\title{
Managerial Views on Corporate Financing Decision
}

\section{Prem Prasad Silwal*}

\begin{abstract}
This survey examines the extent financial executives use the assumptions and/or inputs of capital structure models generated by academicians in making corporate financing decisions. To gather the views, opinions and perceptions of financial managers regarding corporate capital structure practices a questionnaire survey was conducted. The primary data are used in this study, generated through field study based on questionnaire that obtained from the respondents. One hundred and fifty questionnaires were distributed and eighty six of which were collected and analyzed. Nepalese executives believe that excessive use of debt will increase the cost of fund in its capital structure and they also believe that capital structure evolve as the cumulative outcome of past attempt to time the equity market. Similarly, eighty one per cent of the respondents believe that EFWAMB ratio is one of the important predictive variables of the capital structure choice.
\end{abstract}

Key words: Corporate finance, perceptions, cumulative outcome, external financing weighted average market to book ratio

*Mr. Silwal, M.Phil in finance, is a senior Faculty of Finance at Nepal College of Management, Kathmandu University. Email: silwal.prem328@gmail.com. Currently Ph.d. scholar at Tribhuvan University. 


\section{Introduction}

The inmost issues in corporate finance relates to the choice between debt and equity. The debate on capital structure decision has been driven by the empirical work of Modigliani and Miller (1958). These pioneers of finance put the question of the pertinence of capital structure. They disclose that capital structure decisions do not affect firm value when capital markets are perfect, corporate and personal tax do not exist, and firm's financing and Investment decisions are independent. While one or more of the MM assumptions are relaxed, many authors discuss how value of the firm may vary due to the changes in debt equity decision. Most frequently, the optimal capital structure maximizes firm value by simultaneously minimizing external claims to the cash flow stream flowing from the firm's assets.

Static tradeoff theory suggests that there is an optimal capital structure determined by the tax structure, cost of financial distress and agency problem. Another theory of capital structure propounded by Myers and Majluf (1984) discuss the impact of asymmetric information in case investors are less informed about the value of the firm than that insiders. As such investors perceive equity issues are bad news because the firm is expected overvalued results from securities would be underpriced. To overcome this undervalued problem, firm should adopt a financing hierarchy commencing by internal equity followed by debt and equity as last resort. Recently, the market timing theory has challenged both static trade-off and pecking order theories by assuming that observed capital structure is the outcome of past abilities to time equity issues.

Until recently, the capital structure debate was mainly a theoretical one, with the relevance or irrelevance of financing decisions turning on modeler's willingness to accept the existence of significant market imperfection (Miller, 1977, DeAngelo and Masulis, 1980, Kim, 1978, Jensen and Meckling, 1976, Smith and Warner, 1979) for different perspectives on the relevance of the market imperfections. However, empirical evidence summarized nicely by Smith (1986), now strongly indicates that changes in capital structure can affect firm value. Thus, focus of the debate has shifted from whether capital structure decisions matter to why they matter (Pinegar and Wilbricht, 1989).

Eighty nine per cent or 188 out of 212 respondents indicated that they do use some measure of leverage in arriving at their firm's debt-equity mix (Scott and Johnson, 1982). They revealed that most important influence of the setting of target leverage is firm's own management and staff analysts. 87 per cent of the respondent ranked this item first. 
Similarly, sixty-nine percent of the responding firms reported some use of the times interest earned ratio and fifty per cent use long term debt to net worth ratio to measure the leverage position. The most important item affecting corporate debt decisions is management's desire for financial flexibility (Pinegar and Wilbricht (1989). Graham and Harvey (2001) reveal that fifty nine per cent of the respondents value financial flexibility for their desire debt decision. They further contended that the window of opportunity is most important for firms suffering from informational asymmetries. While stock prices increases the firm tends to issue new equity rather than debt. But how far these results correspond in Nepalese context is yet to be seen. Thus, this survey has been conducted by using the modified version of questionnaire of Scott and Johnson (1982) and Pinegar and Wilbricht (1989), Graham and Harvey (2001).

One explanation of why security prices respond to announcement of capital structure change is that firms are moving closer to their optimal capital or target capital structure. Another explanation is that capital structure decisions are irrelevant but that the information they convey concerning the firm's investment opportunities causes security holders to revise their expectations of the firm's prospects. Allen (1991) revealed that internal financing was the most preferred source of financing and in Nepalese context Pradhan and Ang (1994) found that the similar result with Allen. However, in recent period, how far these results consistent in Nepalese context are yet to be seen. Therefore, this study has been motivated by the results of these studies.

It is well observed fact that capital structure is implicitly based on a development of capital market of the country as capital markets are the major place in providing long term source of financing for economic development of the country. Nepal being a capital deficient country has no second alternative than to develop capital market to manage scarce resources efficiently within the economies (Adhikari, 2013). However, investors consider several factors may affect their financing decision.

This study mainly aimed at ascertaining corporate financing practices of Nepalese nonfinancial firms. Specifically, it aimed at revealing capital structure practices in corporate firms based on market timing variables. Capital structure has never received so much of attention as in the recent years mainly due to the growth of number of non-financial firms on the one hand and on the other, to some extent increase number of corporate failures*. Thus, this study has been considered important to provide capital structure practices in Nepalese enterprises through survey. 
* Fago (2006), Mahato (2013): Conducted a study on corporate failure in Nepal results that lack of profitability, the firms lead towards failure. On the other, business failure is evident from the innermost amassed loss over the years in public body and closure some private firms.

The rest of the paper proceeds in order of review of prior managers' views in section II, data and methodology in section III, survey findings presented in section IV, concluding remarks in section $\mathrm{V}$ and finally suggestion for managerial implication are displayed in section VI.

\section{Review of prior Managers' views}

Scott and Johnson (1982) conducted a survey of 212 financial executives with the response rate was 21.2 percent and the result reveals that firms use target leverage ratio and most important influence on these target is firm's own management group and staff of the analysts. Myers and Majluf (1984) reveals that managers use of private information to issue risky securities is driven not by the cost and benefits of debt of trade off model, but rather by the firm's net cash flows. According to them, firm prefers internal equity followed by debt and equity is the lending of the last resort.

Titman and Wessels (1988) employ linear structural modeling to explicitly accommodate explanatory variables as proxies for their theoretical counterparts. Their results show that asset uniqueness and profitability were significantly negatively associated to leverage. The result is consistent with Pecking order hypothesis.

Pinegar and Wilbricht (1989) assert that managers follow a financing hierarchy than to maintain a target debt equity ratio. They further reveal that financial principles are more important in governing the financing decisions of the firm than are specific capital structure theories. Moreover, the capital structure decision is less binding than either the investment or the dividend decision of the firm.

Harris and Raviv (1990) Explore that firms with more tangible assets should take more debt. It is due to the behavior of managers who refuse to liquidate the firm even when the liquidation value is greater than the value of the firm as going concern. Indeed, by mounting the debt, the probability of default will increase which is to the benefit of the shareholders, in agency theory, debt has another punitive position.

Norton (1991) reveals a result from the questionnaire survey of 405 firms, taken from the lists of successful high growth corporations; 27.2\% returned usable responses. Analysis of the responses indicates that tax factors and management preferences have major 
impacts on capital structure. Implications arising from agency cost, information asymmetry, and signaling theory apparently have

little impact on capital structure choice and financing strategies of the responding firms.

Hart and Moore (1995) observe the role of long term debt in controlling management's capability increasing funds for future investment projects. It was analyzed that long term debt may restrict self-interested managers from financing non-profitable investments entailed a direct variation of long term debt with market to book ratio. Therefore, the relationship between growth opportunity and maturity structure had an experimental issue.

Graham and Harvey (2001) surveyed managers' views on practice of corporate finance. The analysis was based on the responses of 392 responding managers. The survey reveals that financial flexibility and credit ratings are the major components considered by the firm while issuing debt. They further reveal that firm tend to issue equity while equity price appreciate in the market.

A study conducted by Baker and Wurgler (2002) raise the question of ability of the theoretical issues: tradeoff and pecking order to explain the observed corporate capital structures. They argue that low leverage firms tend to be those that raised funds when their valuations were high, and conversely, high leverage firms tend to be those that raised funds when their valuations were low. They report that historical market to book ratio has a significantly and economically significant impact on the current capital structure. They result that observed capital structures reflect the cumulative outcome of timing the equity market.

Bancel and Mittoo (2004) conducted a survey on managers of seventeen countries of Europe on their capital structure choice and its determinants with an objective to explore the link between theory and practice of capital structure. The survey results that financial flexibility, credit ratings and tax advantage of debt are the most important factors influencing debt policy while the earnings per share dilution is the most important concern in issuing equity. Additionally, level of interest rate and share price are also equally important in debt equity choice.

A survey conducted by Beattie et al., (2006) on corporate financing decision in UK based listed firms and result reveal that half of the firms seek to maintain target debt level, consistent with trade off theory, but 60 per cent claim that they follow financing 
hierarchy, consistent with pecking order hypothesis. These two theories are considered by the respondents as either mutually exclusive or extensive. The study further reveals that interest tax shield, financial distress; agency cost and information asymmetry are major factors of financing decision.

Cole (2013) examines the managerial views on financing decisions of privately held US firms using data from four nationally representative surveys conducted from 1987 to 2003. Book leverage, as measured by either the ratio of total loans to total assets or the ratio of total liabilities to total assets, is negatively related to firm age and minority ownership; and is positively related to industry median leverage, the corporate legal form of organization, and to the number of banking relationships.

Lambert and Gossel (2016) conducted a survey on capital structure decisions in South Africa from the perspective of Chief Financial Officer. The result of a survey of 33 CFOs of listed companies reveals that South African CFOs are equally likely to follow Pecking Order and Static Trade Off theories. However, small companies are more likely to follow the Pecking Order theory while large firms are more likely to follow static trade off theory of capital structure. The study further asserts that South African firms are more likely to follow trade off theory than that of the companies from other emerging countries.

A survey conducted by Pradhan and Ang (1994) revealed that bank debt and retained earnings are the most preferred source of financing in the Nepalese firms capital structure. The study was in line with pecking order hypothesis as firm prefer internal equity followed by straight debt and lastly to the equity financing.

Sherpa (2007) conducted a survey on corporate capital structure decision in Nepalese firms. 120 questionnaires were distributed and 74 of which were collected. The result reveals that financial flexibility, availability of internal funds and cash flow volatility are the influential factors for the financial executives while making financing decision. The study further concludes that investment decision is the most important finance function followed by financing decision, preparing report and the least one is maintaining good relation with shareholders.

Adhikari (2010) surveyed the opinions of financial executives on capital structure and cost of capital of Nepalese firms. 127 responses were collected and result reveals that the market price of firms' common stock being adversely affected if they use excessive 
amount of debt. He further concluded that Nepalese firms use financing hierarchy while they employ different types of financing resources in their firm.

Silwal (2015) surveyed the views of corporate financial executives on debt-equity choice of Nepalese non-financial firms listed in Nepal Stock Exchange. The analysis of the responses obtained from 76 respondents revealed that on debt-equity choice firms put higher stress on debt asset ratio followed by debt equity ratio, retained earnings and the least important one is sales turnover in their financing decision. Similarly, he also conducted a study of secondary data analysis of Nepalese manufacturing firms on debt equity choice, the discriminant analysis and binary logistic regression were used and results reveal that liquidity and profitability are the major determinants of capital structure decision.

The review of aforementioned studies revealed that there are various surveys conducted in developed countries on capital structure decisions, and very few surveys of financial executives have been conducted in Nepalese firms and some of them are also connected with financial institutions. Thus, there is a need of conducting another survey of manager's views on confining the multifarious aspects of capital structure practices in Nepal.

\section{Data and Methodology}

To gather the views, opinions and perceptions of financial managers regarding corporate financing decision a questionnaire survey was conducted. The primary data are used in this study, generated through field study based on questionnaire that obtained from the respondents. The pro-forma of structured questionnaire for the managers' views on capital structure practices on non-financial firms of Nepalese enterprises can be requested through: NCM research department.

The questionnaire were distributed to chief financial officers, finance executives and accounts executives of various firms like manufacturing, hotels, hydro, trading and service firms. The questionnaire survey consists of 20 different types of questions related to capital structure management.

\section{A. Sample Selection and responses retrieved}

The survey was conducted by distributing 150 questionnaires to the financial executives of the non-financial firms located in Kathmandu, and Lalitpur districts based on the corporate office of selected firm and a total of 86 responses were 
received which were useful for the analysis and 16 were returned without completion. Thus, the response rate of this study is 57.33 per cent of the total distribution.

\section{Table 1}

Sampling frame for survey of financial executives on capital structure practices and responses retrieved. The table reveals the sampling framework for survey of financial executives of non-financial firms and responses retrieved on capital structure practices. There were 222 firms listed in NEPSE as on mid of July 2014. A total of 150 questionnaire were distributed to the financial executives from the selected firms for survey. The financial executives comprises chief financial officers, chairman, director, financial managers and others (managers are in decision making level).

\begin{tabular}{|c|l|c|c|c|c|}
\hline S.N & Groups & $\begin{array}{c}\text { Number of } \\
\text { listed } \\
\text { enterprises }\end{array}$ & $\begin{array}{c}\text { Number of financial } \\
\text { executives selected } \\
\text { for survey }\end{array}$ & $\begin{array}{c}\text { Number of } \\
\text { responses } \\
\text { received }\end{array}$ & $\begin{array}{c}\text { Responses } \\
\text { percentage }\end{array}$ \\
\hline 1 & M \& P & 18 & 60 & 43 & 71.67 \\
\hline 2 & Hotels & 4 & 20 & 13 & 65.00 \\
\hline 3 & Hydro & 11 & 30 & 13 & 43.33 \\
\hline 4 & Trading & 4 & 20 & 10 & 50.00 \\
\hline 5 & Other & 3 & 20 & 7 & 35.00 \\
\hline & Total & 41 & 150 & 86 & 57.33 \\
\hline
\end{tabular}

Source: Annual reports of respective listed firms, Nepal Stock Exchange data base, and Security Board of Nepal data base for the year ending July, 2014..

\section{B. Statistical tools used}

\section{(i) Composite mean and rank}

Likert scale questionnaire was distributed to the respondents and were asked to rate each variable they recognize important in market timing and capital structure. The value 1 is assigned as most important and 5 as least important. The mean weight is used in this study to analyze the primary data and inferences are drawn from them. The degree of importance of each value to the overall total is measured by mean weight. Mean weights are calculated to rank the issues, raised on questionnaire based on their importance as mentioned by the respondents. The variables are ranked on the basis of weighted mean value 
where the lowest value indicates the most important and the highest value is the least important.

\section{(ii) Chi-square Test}

Chi-square is a measure of statistical tool used in the context of sampling analysis for comparing a variance to a theoretical variance. In this study, chisquare values are computed to examine whether views of financial executives on capital structure differ between the respondents of manufacturing and nonmanufacturing firms.

The value of test statistic is

$$
\chi^{2}=\sum_{i=1}^{n} \frac{\left(O_{\left.i-E_{i}\right)}{ }^{2}\right.}{E i}
$$

Where,

C. = Pearson's cumulative test statistic which asymptotically approaches a $\chi^{2}$ distribution; $\mathrm{O}_{\mathrm{i}}=$ observed frequency; $\mathrm{E}_{\mathrm{i}}=$ Expected (theoretical) frequency; $\mathrm{n}=$ number of paired observations

$\mathrm{E}=$ Number of questionnaire distributed/Number of response retrieved

\section{Respondent profile}

In order to obtain the precise views of respondents on corporate financing decision, it is important that well experience individuals with a broad knowledge of the types financing sources advanced throughout their enterprises fill up the questionnaire. Thus, it was attempted to survey the views of chief financial officer, director, manager and financial executives of debt employed firm. The general background of the respondents as well as sample firms is presented in the figure1 (Panel A, B, C, D and $\mathrm{E})$.

\section{Table 1}

\section{Respondents proflie}

This figure shows the profile of responding financial executives. The line of busines indicates the types of business selected in this sample, position indicates that the level of financial executives in their organization, age indicates the age of 
74 | The International Research Journal of Management Science Vol. 2 No. 1 Decm.2017/ISSN 2542-2510 respondentsand age of the firms and the experience indicates the working experience of financial executives in financing decision and firm age.

Panel A

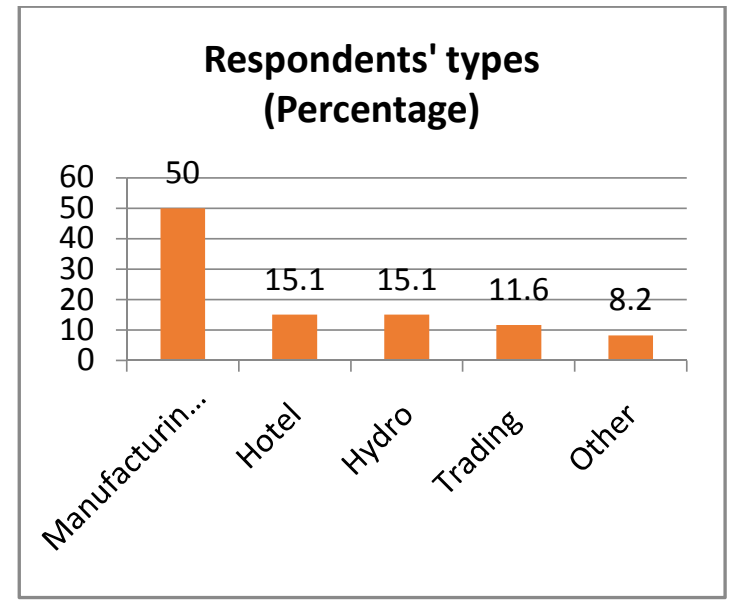

Panel B

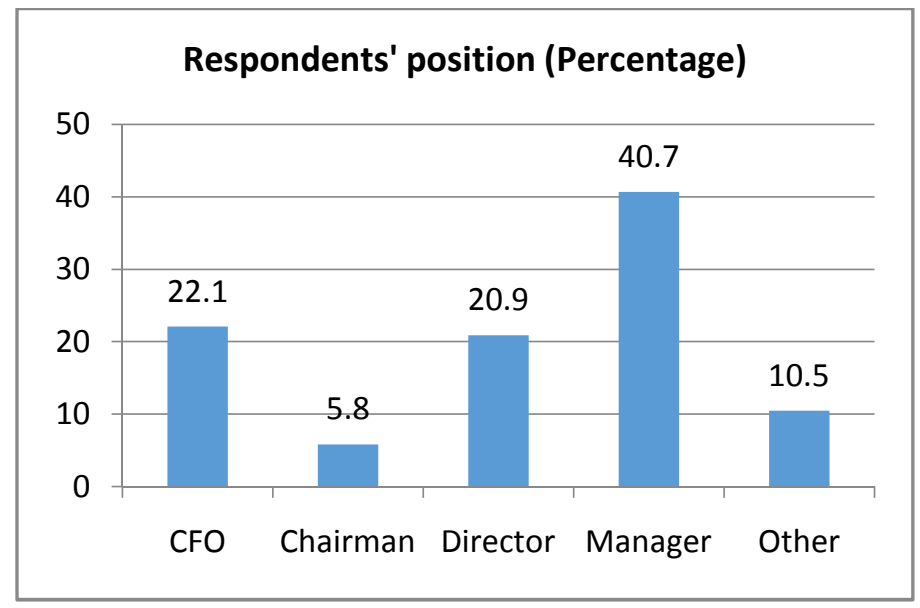


Panel C

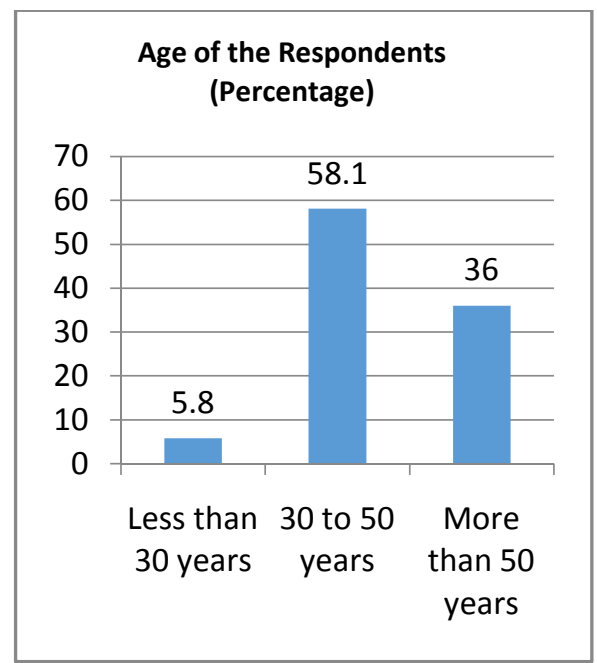

Panel D

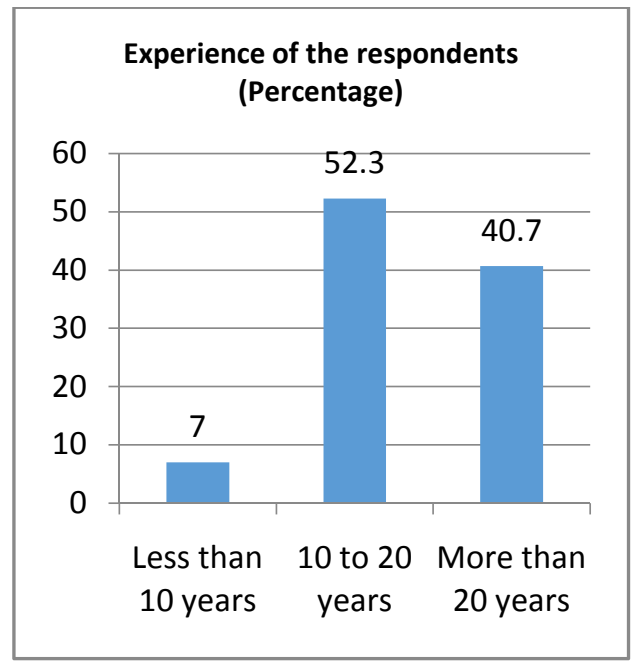

Panel E

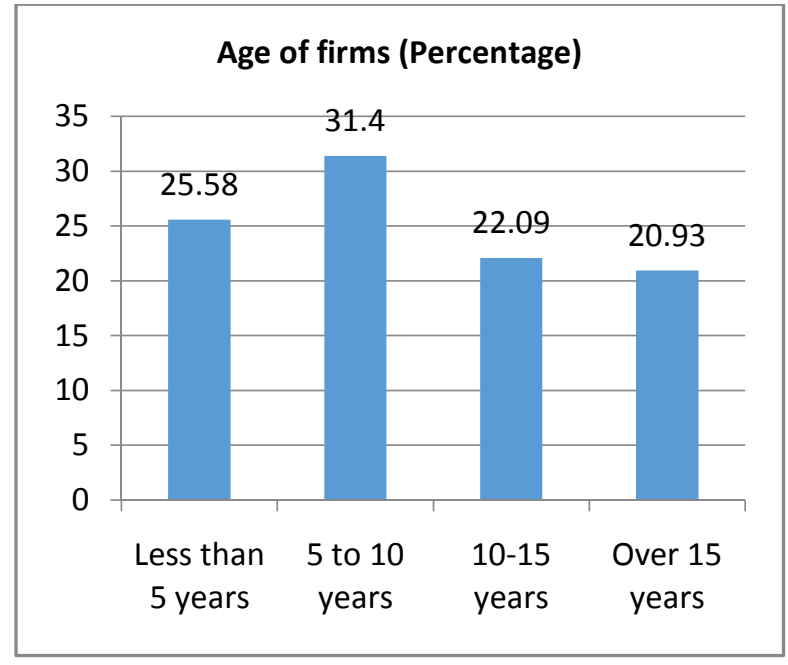

As regards of the line of business in figure 1 (panel A), the majority of the respondents are from manufacturing and processing representing 50 per cent of the total respondents on survey result of 2014 followed by hotel (15.1 per cent), hydro (15.1 per cent), trading (11.6 per cent) and other sectors representing 8 per cent. The conjecture of this classification is that the leverage structure of this type of industry differs. The classification is made on the assumption of financial executives may be involved in capital structure decision. 
Panel B provides the information regarding the position held by the respondents in their concerned firms. Out of total respondents, 19 respondents (22 per cent) are chief financial officers and 5 respondents ( 6 per cent) are chairman, 18 ( 21 per cent) respondents are directors, 35 (41 per cent) are financial managers and 9 (10 per cent) are others.

As evident from the panel E, 26 per cent of the firms covered by this study are of less than 5 years old, 31 per cent are of 6 to 10 years, 22 per cent are of 11 to 15 years and the rest are more than 15 years.

\section{Survey Analysis}

The responses of financial executives on major aspects of capital structure decisions were analyzed in total sample first and then categorized manufacturing and non-manufacturing firms into two groups for comparative analysis. The overall results of chi-square test is presented in Appendix I. Results of survey were compared with prior research findings of western countries including Nepal where possible. The details of results are presented here as under:

\section{A. Corporate finance: Theory and Practice}

Executives rely heavily on practical, informal rules when choosing capital structure in Nepalese non- financial firms. The respondents were asked about what kind of factors affecting financing decision, who are the most influential decision makers in firm's financing, how market timing affect capital structure decision, and what sources of fund the firms use in their capital structure. The survey also has been attempted to uncover the theory of capital structure from the managerial practices by opinions of corporate executives. The survey also tried to reveal the financing hierarchy in Nepalese context.

The most important factors affecting debt policy are profitability of the firm, issuing debt while profits are not enough, market condition, issuing debt gives better signal and historical market to book ratio. The result is consistent with the study of Baker and Wurgler (2002). When issuing equity, respondents are concerned about firms' profitability and recent stock price appreciation. While raising fund for new project, financial executives rely more importantly on financial flexibility and market price of the stock. 


\section{B. Source of capital}

This section is designed to receive the opinion of respondents used in survey to know the sources of fund used by the firm to meet its new investment project among Nepalese companies. The survey contains the three options altogether to know the real information on financing source of all the sampled firms. The corporate executives are asked to choose the source of capital they employed in the firm from 1) Equity capital 2) Debt capital and 3) A combination of debt equity capital and the responses obtained are shown in table 2 . The table indicates that a combination of debt-equity capital is the major source of capital. 68.6 per cent respondents' choice is to use both source of capital whereas 18.6 per cent used equity capital and the least 12.8 per cent used debt capital.

Table 2

\section{Source of capital}

This table displays the responses to the question whether the respondents' firms employ equity capital or debt capital or combination of both capital. The relative frequency and percentage have been presented in the table below.

\begin{tabular}{|l|l|c|}
\hline \multicolumn{1}{|c|}{ Sources } & Frequency & Percentage \\
\hline Equity capital & 16 & 18.6 \\
\hline Debt Capital & 11 & 12.8 \\
\hline Combination of debt-equity capital & 59 & 68.6 \\
\hline Total & 86 & 100.0 \\
\hline
\end{tabular}

Questionnaire survey 2014

\section{Measure of financial leverage}

The respondents' were asked to choose Yes or No whether they use some measure of financial leverage (debt equity ratio or times interest earned ratio) as a constraint on the mix of debt and common equity funds employed and the responses obtained have been presented in table 2 . The majority of the respondents ( 80.2 per cent) believed that they employ some financial tools such as debt-equity ratio and times interest earned ratio in measuring financial leverage whereas 19.8 per cent express their views that they do not use this kind of financial measure. The result indicates that Nepalese financial executives use some financial tools to measure their leverage. 


\section{Capital structure theory: Managerial Perspective}

The table 3 reveals the results of various questions that are designed to examine respondents' opinion about leverage financing and capital structure decision. Results, to some extent, provide additional insight into contending corporate financing decision.

\begin{tabular}{|c|c|c|c|c|}
\hline \multicolumn{5}{|c|}{ Measure of financial leverage } \\
\hline & & Yes & No & Total \\
\hline & & $69(80.2)$ & $17(19.8)$ & $86(100)$ \\
\hline \multicolumn{5}{|c|}{ Excessive use of debt increase cost of debt } \\
\hline & Yes & No & $\begin{array}{l}\text { Don't } \\
\text { know }\end{array}$ & Total \\
\hline Frequency & $60(69.8)$ & $11(12.8)$ & $15(17.4)$ & $86(100)$ \\
\hline \multicolumn{5}{|c|}{ Capital structure is cumulative outcome of past attempt to market timing } \\
\hline & Yes & No & $\begin{array}{l}\text { Don't } \\
\text { know }\end{array}$ & Total \\
\hline Frequency & $70(81.4)$ & $4(4.7)$ & $12(14)$ & $86(100)$ \\
\hline \multicolumn{5}{|c|}{ EFWAMB ratio is an important predictor of issuing debt or equity } \\
\hline & Yes & No & $\begin{array}{l}\text { Don't } \\
\text { know }\end{array}$ & Total \\
\hline Frequency & $70(81.4)$ & $7(8.1)$ & $9(10.5)$ & $86(100)$ \\
\hline \multicolumn{5}{|c|}{ Increase the market price per share } \\
\hline & Agree & Disagree & $\begin{array}{l}\text { Don't } \\
\text { know }\end{array}$ & Total \\
\hline Frequency & 67(77.9) & $11(12.8)$ & $8(9.3)$ & $86(100)$ \\
\hline \multicolumn{5}{|c|}{ Decrease the overall cost of capital } \\
\hline & Agree & Disagree & $\begin{array}{l}\text { Don't } \\
\text { know }\end{array}$ & Total \\
\hline Frequency & $68(79.1)$ & $13(15.1)$ & $5(5.8)$ & $86(100)$ \\
\hline \multicolumn{5}{|c|}{ Increase leverage } \\
\hline & Agree & Disagree & $\begin{array}{l}\text { Don't } \\
\text { know }\end{array}$ & Total \\
\hline Frequency & $14(16.3)$ & $66(76.7)$ & $6(7)$ & $86(100)$ \\
\hline \multicolumn{5}{|c|}{ Decrease Leverage } \\
\hline & Agree & Disagree & $\begin{array}{l}\text { Don't } \\
\text { know }\end{array}$ & Total \\
\hline Frequency & $68(79.1)$ & $13(15.1)$ & $5(5.8)$ & $86(100)$ \\
\hline \multicolumn{5}{|c|}{ Optimal/target capital structure } \\
\hline & & Optimal & Target & Total \\
\hline \multicolumn{2}{|c|}{ Frequency } & $23(26.7)$ & $63(73.3)$ & $86(100)$ \\
\hline
\end{tabular}




\begin{tabular}{|c|c|r|r|r|}
\hline \multicolumn{5}{|c|}{ Tax reform Act 2014 results increase/decrease the proportion of debt } \\
\hline & Increase & Decrease & Unchanged & Total \\
\hline Frequency & $33(38.4)$ & $34(39.5)$ & $18(20.9)$ & $85(98.8)$ \\
\hline \multicolumn{5}{|c|}{ Estimated time that firm's security priced fairly by the market } \\
\hline \multicolumn{7}{|c|}{$\begin{array}{c}>80 \% \text { of the } \\
\text { time }\end{array}$} & $\begin{array}{c}50 \text { to } 80 \\
\% \text { of the } \\
\text { time }\end{array}$ & $\begin{array}{c}<50 \% \text { of } \\
\text { the time }\end{array}$ & Total \\
\hline Frequency & $19(22.1)$ & $53(61.6)$ & $14(16.3)$ & $86(100)$ \\
\hline
\end{tabular}

As evident from this table, 70 per cent of the respondents believed that excessive use of debt will increase the cost of capital structure while 13 per cent did not believe so and remaining 17 per cent respondents express that they have no idea on this issue. The chi-square test indicated that the opinions of manufacturing and nonmanufacturing groups are similar and that there is no significant difference with respect to excessive use of debt (Appendix 1).

Similarly, the result reveals that 81.4 per cent respondents believed that capital structure evolve as the cumulative outcome of past attempts to time the equity market whereas 4.7 per cent did not believe so and 14 per cent express their views as they do not have any idea. This indicates that Nepalese financial executives consider capital structure as the outcome of past market timing and the result is consistent with Baker and Wurgler (2002) study. Likewise, 81.4 per cent of the respondents believe that EFWAMB ratio is one of the important predictive variables of the capital structure choice while 8.1 per cent did not believe it and remaining 10.5 per cent of the respondents have no idea. The chi-square (calculated value $8.56>$ tabulated value 5.99 at 5\%) test indicated that the views of manufacturing and nonmanufacturing firms are not similar with respect to capital structure's cumulative outcome of past attempt to market timing.

Financial executives were asked whether optimal use of capital structure increase market price per share or decrease the overall cost of capital. Majority of the respondents (78 per cent) believed that optimal use of capital structure increases the market price of stock whereas 13 per cent did not agree and the remaining 9 per cent of respondents were in confusion whether it is correct or not. Similarly, 79 per cent respondent agreed that optimal use of capital structure reduces the cost of capital while 15 per cent denied it and remaining 9 per cent of the respondent had no idea. 
Moreover, a series of questions that asked managers to indicate to what extent they felt their securities were fairly priced also produced results suggestive of a signaling scenario. Although almost one fourth of the managers ( 22 per cent) indicated that their securities were correctly priced more than 80 per cent of the time. However, more than half of the managers (62 per cent) indicated that their securities were correctly pricing between 50 and 80 per cent of the time, and 16 per cent said their securities were correctly priced less than 50 per cent of the time. Hence, many respondents did agree with the notion of efficient market at least some part of the time. This provides support for the Pinegar and Wilbricht (1986) study from managerial perspective.

\section{E. Most important setting in firm's target financial structure}

The respondents were asked to rank different setting on a scale of 1 (most important) to 5 (least important) and the responses obtained are presented in table 4. As this reveals that top management is appeared to be the most influential finance setting in Nepalese firms. The result (mean score 1.11) seems obvious since organizational team needs to spend lots of time in managing their financial structure. The result is consistent with the study of Scott and Johnson (1982). Three important things are to note that second priority is assigned to staff analysts (mean score 2.17 ), third priority goes to commercial bankers (mean score 2.87) and the least priority assigned to comparison with ratios of industry competitors (mean score 5.15). It results that there is no industry trend through which a comparison can be ascertained.

\section{Table 4}

Most important setting in capital structure decision



\section{F. Pattern of financial leverage}


The relative extent to which the many leverage measures are employed in corporate sector, however, is not generally known. So the financial executives are asked to rank the relative importance of seven leverage ratio to specify on a scale of 1 to the most important, 2 to the less important one and so on.

\section{Table 5}

Measurement of financial leverage

Survey responses to the question: How does your firm measure the degree of financial leverage? The table displays different financial leverage along with their mean value and ranking. The mean score is calculated as follows: $(61.6 \times 1+25.6 \times 2+7 \times 3+1.2 \times 4+4.7 \times 5) / 100=1.62$ and so on.

\begin{tabular}{|c|c|c|c|c|c|c|c|c|}
\hline \multicolumn{8}{|c|}{ Percentage of respondents within each rank } & \multirow[b]{2}{*}{$\begin{array}{l}\text { Ran } \\
\mathrm{k}\end{array}$} \\
\hline Leverage & 1 & 2 & 3 & 4 & 5 & $\mathrm{~N}$ & Mean & \\
\hline Total liabilities divided by total assets & 61.6 & 25.6 & 7 & 1.2 & 4.7 & 86 & 1.62 & 1 \\
\hline Times interest earned ratio & 18.6 & 50 & 14 & 12.8 & 3.5 & 86 & 2.29 & 2 \\
\hline Long term debt divided by total assets & 22.1 & 30.2 & 23.3 & 23.3 & 1.2 & 86 & 2.52 & 3 \\
\hline Long term debt divided by total debt plus net worth & 7 & 45.3 & 38.4 & 5.8 & 3.5 & 86 & 2.53 & 4 \\
\hline Cash flow coverage ratio & 23.3 & 31.4 & 23.3 & 7 & 15.1 & 86 & 2.59 & 5 \\
\hline Common equity divided by total assets & 7 & 27.9 & 41.9 & 19.8 & 3.5 & 86 & 2.85 & 6 \\
\hline Long term debt divided by net worth & 11.6 & 20.9 & 27.9 & 29.1 & 10.5 & 86 & 3.06 & 7 \\
\hline \multicolumn{8}{|c|}{$\begin{array}{l}\text { Respondents are asked to rank on a scale of } 1 \text { (most important) to } 2 \text { (next most important) and so on. The table } \\
\text { presents the percentage of respondents, number of total respondents, mean value and their rank. }\end{array}$} & \\
\hline
\end{tabular}

Total liabilities divided by total assets is appeared to be the most important one as shown in table 5. It is obvious since Martin and Scott (1974), Rajan and Zingales (1995) used total debt divided by total assets as leverage in the firms' capital structure which is one of the mostly used financial tools to measure the financial leverage of the firm. The times-interest earned ratio is ranked as second most important financial tool in leverage metric. The third most priority is assigned to long term debt divided by total assets and the least important is assigned to long term debt divided by net worth. However, the long term debt to net worth ratio was highly ranked in Scott and Johnson (1982) study. But this result surprisingly differs from his study. 


\section{G. Static tradeoff versus Pecking order hypothesis}

Tradeoff theory suggests firms to have a target capital structure which is determined by balancing the costs and benefits of debt financing. If a firm over is leveraged compared to its target capital structure, tradeoff theory predicts the firm to lower its debt ratio in subsequent periods. This model indicates that firms maintain a target debt-equity ratio that maximizes firm value by minimizing the cost of prevailing the market imperfections. But in contrast to this theory, pecking order theory states that companies prioritize their sources of financing (from internal financing to external equity) according to the law of least effort, or of least resistance, preferring to raise equity as a financing means "of last resort". Hence, internal funds are used first, and when that is depleted, debt is issued, and when it is not sensible to issue any more debt, equity is issued.

\section{Table 6}

\section{Preference of long term source of financing}

The table displays the percentage of responses within each source of financing. Respondents are asked to rank on a scale of 1 (most important) to 6 (least important).A score of 0 is assigned when a source is not ranked. The table reveals the percentage of respondents, number of total respondents, composite mean and their rank. This composite mean is derived from all the responses to the questionnaire and varies inversely with the important of use. The smaller composite mean rank indicate that the most preferred source of financing and highest mean score indicate that least preferred source of financing in firms' investment.

\begin{tabular}{|c|c|c|c|c|c|c|c|c|c|}
\hline Source of financing & 1 & 2 & 3 & 4 & 5 & 6 & $\mathrm{~N}$ & Mean & Rank \\
\hline Internal equity financing & 75.60 & 20.90 & 3.50 & 0.00 & 0.00 & 0.00 & 86 & 1.29 & 1 \\
\hline Straight debt financing & 12.80 & 66.30 & 16.30 & 2.30 & 1.20 & 1.20 & 86 & 2.17 & 2 \\
\hline External equity financing & 7.00 & 8.10 & 70.90 & 9.20 & 1.20 & 3.50 & 86 & 2.99 & 3 \\
\hline Straight preferred stock financing & 1.20 & 2.30 & 5.80 & 54.70 & 27.90 & 8.10 & 86 & 4.31 & 4 \\
\hline Convertible debt financing & 1.20 & 1.20 & 1.20 & 29.10 & 46.50 & 20.90 & 86 & 4.81 & 5 \\
\hline Convertible preferred stock financing & 3.50 & 1.20 & 1.20 & 4.70 & 22.10 & 67.40 & 86 & 5.43 & 6 \\
\hline
\end{tabular}

Questionnaire survey 2014

Table 6 reveals the preferences for the financing hierarchy of the corporate executives. The results show that the use of internal source of fund is ranked first followed by straight debt financing and external equity financing. Similarly, straight debt financing dominates convertible debt which supports the result of Pineger and 
Wilbricht (1989) as they found the mean rank of straight debt and convertible debt are 4.88 and 3.02 respectively.

\section{Financing planning principles}

Managers' relative disinclination toward capital structure theory, in general, is further reflected in their rankings of six financial principles summarized in table 8 . The respondents were asked to make the financing decision regarding which financing planning principles are more important in governing their firms' financing need.

\section{Table 7}

\section{Financial planning principles}

The table indicates the percentage of responses within each rank. Ranking of the importance is $1=$ most important to $6=$ least important. Composite mean rankings are calculated by assigning scores of 1 through 6 for ranking from most important to least important correspondingly and multiply each score by the fraction of responses within each rank. Relative importance of various financial planning principles in governing financing decision of non financial Nepalese firms.

\begin{tabular}{|c|c|c|c|c|c|c|c|c|}
\hline \multirow[b]{2}{*}{ Financial planning principles } & \multicolumn{7}{|c|}{ Percentage of response within each rank ${ }^{\mathrm{a}}$} & \multirow[b]{2}{*}{ Rank } \\
\hline & 1 & 2 & 3 & 4 & 5 & 6 & Mean & \\
\hline Maximizing prices of publicly traded securities & 57 & 19.8 & 11.6 & 5.8 & 2.3 & 3.5 & 1.83 & 1 \\
\hline Maintaining financial flexibility & 23.3 & 34.9 & 20.9 & 9.3 & 8.1 & 3.5 & 2.54 & 2 \\
\hline Ensuring long term survivability of the firm & 22.1 & 32.6 & 20.9 & 16.3 & 4.7 & 3.5 & 2.59 & 3 \\
\hline Maintaining financial independence & 3.5 & 8.1 & 14.4 & 19.8 & 30.2 & 20.9 & 4.18 & 4 \\
\hline Establishing comparability with firms in the industry & 2.3 & 5.8 & 1.6 & 20.9 & 27.4 & 31.9 & 4.31 & 5 \\
\hline Maintaining a predictable source of funds & 1.2 & 11.6 & 17.4 & 24.4 & 12.8 & 32.6 & 4.33 & 6 \\
\hline \multicolumn{9}{|l|}{$\begin{array}{l}\text { These estimates are based on } 86 \text { responses. } \\
\text { of } 0 \text { is assigned when a source is not ranked }\end{array}$} \\
\hline
\end{tabular}

The importance of capital structure decisions relative to other decisions managers' interest can be assessed by examining responses on the basis of six financial principles. As is evident from the table, maximizing prices of publicly traded securities, maintaining financial flexibility and ensuring long term survivability of the firm are the three most important financial planning principles considered in governing Nepalese firms' financing decision. As depicted in the table, three of the six principles there have been ranks of 2.59 or less. This result shows that two 
important things to note are the first priority assigned to maximizing prices of traded security and the least priority assigned to maintaining a predictable source of funds.

\section{H. Finance Functions}

In order to examine the finance function on capital structure decision, a question was included in the survey questionnaire, which included various functions. Participants were asked to rate each function on a scale of 1 (very important) to 7 (least important). The survey opinion of this question is depicted in the table 10. When asked participants to rank the relative importance of seven finance functions, financing decision appeared to be the very important finance function. The mean value less than 3 is considered as important finance function in market timing on capital structure whereas value more than 3 is regarded as less important. The value of rank has been assigned from smallest to largest based on the weighted mean. The very important functions have been assigned on the ground of value 1,2 which have been summed up to get the value of very important function. This table shows the weighted mean and rank of each individual seven finance functions considered on the grounds of participants' responses.

Table 9

Finance function

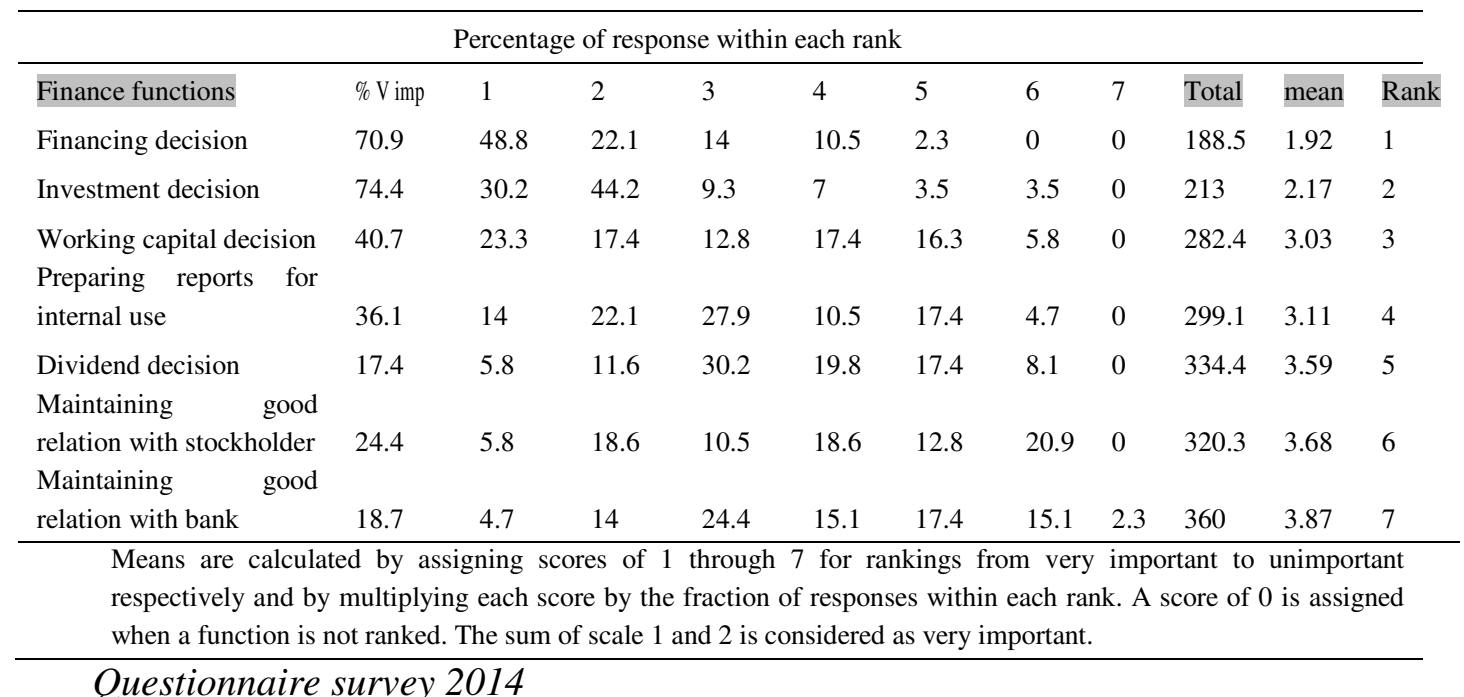

The result is entirely based on the opinion of respondents towards impacts of market timing on capital structure pertaining to their knowledge and experience. The above 
result reveals that finance function is appeared to be most important followed by investment function. The result seems obvious since financial executives need to spend a lot of their time in managing source of finance and planning investment project. The two important things to note are the third priority assigned to working capital decision and the least priority assigned to maintaining good relation with bank.

Not all the factors that affect the capital structure decision lend themselves to quantification. Those being surveyed, therefore, were asked to list in order of importance the qualitative factors that influence the market timing on capital structure in their firms. The responses are summarized in table 10.

\section{Table 10}

\section{Qualitative factors affecting the leverage decision}

This table reveals the percentage of responses within each rank, the percentage of participants who did not rank the factors and mean of the ranking. Ranking of the choice is $1=$ most important, to $4=$ Unimportant.

\begin{tabular}{|c|c|c|c|c|c|c|c|}
\hline \multirow[b]{2}{*}{ Factors } & \multicolumn{4}{|c|}{ Percentage of responses within each rank } & \multicolumn{3}{|c|}{ Not ranked } \\
\hline & 1 & 2 & 3 & 4 & 0 & Mean & Rank \\
\hline Legal & 62.8 & 25.6 & 7 & 4.6 & 0 & 1.53 & 1 \\
\hline Image & 20.9 & 44.2 & 27.9 & 5.8 & 1.2 & 2.16 & 2 \\
\hline Management goals & 23.3 & 25.6 & 40.7 & 9.3 & 1.2 & 2.33 & 3 \\
\hline Employee Morale & 12.8 & 29.1 & 40.7 & 16.3 & 1.2 & 2.58 & 4 \\
\hline Environmental responsibility & 9.3 & 34.9 & 32.6 & 20.9 & 2.3 & 2.6 & 5 \\
\hline Employee safety & 9.3 & 30.2 & 36 & 20.9 & 3.6 & 2.61 & 6 \\
\hline Others & 9.8 & 12.8 & 11.6 & 61.6 & 4.2 & 3.16 & 7 \\
\hline
\end{tabular}

Questionnaire survey 2014

When asked participants to rank the relative importance of seven qualitative factors that affects capital structure decision on a scale of 1 (most important) to 4 (unimportant), the table 10 clearly reveals that majority of the Nepalese managers give more emphasize on legal factors followed by organizational image while making capital structure decision. The mean ranking of these two factors are 1.53 and 2.16 respectively. Management goal has been received third highest mean 
ranking. Legal influences led the factors ranked first in importance by accounting for percentage of response; image and environmental responsibility were in the second and third important position in the study of Petty et al., (1975). However, management goal in capital structure decision is in third position. Since the first two factors of this study related to the capital structure decision, on the basis of findings, it can be concluded that finance managers considered legal and image in financing decision simultaneously.

\section{Concluding Remarks}

The result reveals that the majority of Nepalese executives use both type of capital in their financing decision. Almost sixty nine per cent of the respondents express their views regarding use of combination of debt and equity capital. Likewise, eighty per cent of respondents agreed that they use some type of financial leverage while making financing decision for new investment. Nepalese executives believe that excessive use of debt will increase the cost of fund in its capital structure and they also believe that capital structure evolve as the cumulative outcome of past attempt to time the equity market. Similarly, eighty one per cent of the respondents believe that EFWAMB ratio is one of the important predictive variables of the capital structure choice. The result is consistent with the study of Baker and Wurgler (2002). Similarly, seventy nine per cent respondents agreed that optimal use of capital structure reduces the cost of capital. The result is consistent with the study of capital structure of developing countries (Rajan and Zingales, 1995). The most preferred source of financing is retained earnings followed by straight debt, new equity, straight preferred stock, convertible debt and the least is convertible preferred stock financing. Financial flexibility is also found in Graham and Harvey (2001) study as important factor for financing decision.

The survey found major factors that impact capital structure to be profitability of the firm, issue debts while profits are not sufficient for funding, market condition, issue debt gives investor better signal, historical market to book ratio and growth opportunity while the least important one appeared to be issuing equity gives better signal. In addition to the quantitative factors, the majority of the Nepalese managers give more emphasize on legal factors followed by organizational image while making capital structure decision. It can be concluded that finance managers considered qualitative factors such as legal and image in financing decision simultaneously. 


\section{Suggestion for managerial implication}

There are several dimensions in measuring capital structure decisions. This study focuses in identifying the managerial views in making financing decision. Nepalese investors believe that capital structure evolve as cumulative outcome of the past attempt to time the equity market, thus it is suggested to the financial executive to make financing decision based on past pattern of market to book ratio. Similarly, number of factors such as profitability of the firm, issue debt while profits are enough for funding, historical market to book ratio, issue debt gives better signal, market condition, growth opportunity of the firm and sales stability have been found to be most important. Thus managers should consider these factors while making financing decision.

Nepalese capital market is still in an infant age as there are very less manufacturing firms listed in capital market. Few firms are listed at NEPSE, however, they have poor disclosure practices, highly fluctuating market index and few stockbrokers and investors' dominance in market price. The regulatory bodies such as NEPSE and SEBON should play crucial role in order to make this market more transparent by conducting regular supervision, taking necessary action for the manipulators and defending investors' concern from unethical practices.

The computed chi-square values less than tabulated value (appendix 1 -except excess debt causes to increase cost) indicates that the opinions of the manufacturing and trading firms responding groups are similar and that there is no significant difference with respect to employment of debt capital in their firm.

\section{REFERENCES}

Adhikari, N. (2013). Capital Market Development in Nepal, Reshaping Organizations to Develop Responsible Global Leadership-Conference Proceedings, vol. 1(1), 321334.

Adhikari, P.R. (2010).Capital Structure and the Cost of Capital: The Nepalese Evidence. Unpublished M.Phil. thesis, Faculty of Management, Tribhuvan University, Kathmandu.

Allen, D.E. (1991). The Determinants of Capital Structure of Listed Australian Companies: The Financial Manager's Perspectives. Australian Journal of Management, vol 16, 103-127. 
Baker, M. and Wurgler, J. (2002). Market Timing and Capital Structure. Journal of Finance, vol. 47, 1-32.

Bancel, F. and Mittoo, U.R. (2004). Cross Country Determinants of Capital Structure Choices: A Survey of European Firms. Financial Management, 103-132.

Beattie, V., Goodacre, A. and Thomson, S.J. 2006. Corporate financing decisions: UK survey evidence. Journal of Business Finance \& Accounting, vol. 33(9), 14021434.

Cole, R.A. (2013). What Do We Know about the Capital Structure of Privately Held US Firms? Evidence from the Surveys of Small Business Finance. Financial Management, vol 42(4), 777-813.

DeAngelo, H., and Masulis, R. W. (1980). Optimal Capital Structure under Corporate and Personal taxation. Journal of financial economics, vol. 8(1), 3-29.

Fago, G. (2006). Financial Ratios and Prediction of Corporate Failure in Nepal. Unpublished M.Phil.Thesis, Faculty of Management, Tribhuvan University, Kathmandu.

Graham, J. and Harvey, C. (2001). The Theory and Practice of Corporate Finance: Evidence from the Field. Journal of Financial Economics, vol. 60, 187-243.

Harris, M. and Raviv, A. (1990). The Theory of Capital Structure. Journal of Finance, Vol. 39, pp 127-145.

Hart, O. and Moore, J. (1995). Debt and Seniority: An Analysis of the Role of Hard Claims in Constraining Management. American Economic Review, Vol.85, pp 567585 .

Jensen, M.C. and Meckling, W.H. (1976). Theory of the Firm: Managerial Behavior, Agency Costs, and Ownership Structure. Journal of Financial Economics, vol. 7, pp. 305-360.

Kim, H. (1978). A Mean Variance Theory of Optimal Capital Structure and Corporate Debt Capacity. Journal of Finance, vol. 33, 45-64.

Lambert, D.W. and Gossel, S.J. (2016). South African Capital Structure Decisions: A Survey of Listed Companies. Journal of African Business, vol. 17(2), 167-187.

Mahato, S. (2013). Financial Ratios and Prediction of Corporate Failure in Nepal. Unpublished M.Phil. thesis, Faculty of Management, Tribhuvan University, Kathmandu.

Miller, M. H. (1977). Debt and Taxes. The Journal of Finance, vol. 32(2), 261-275. 
Modigliani, F., \& Miller, M. H. (1958). The cost of capital, corporation finance and the theory of investment. The American economic review, vol. 53, 261-297.

Myers, S. C., and Majluf, N. S. (1984). Corporate financing and investment decisions when firms have information that investors do not have. Journal of financial economics, vol. 13(2), 187-221.

Norton, E. (1991). Capital structure and small growth firms. The Journal of Entrepreneurial Finance, 1(2), 161-177.

Norton, E. (1991). Factors Affecting Capital Structure Decisions. Financial Review, vol. 26 (3), 431-446.

Pinegar, J.M. and Wilbricht, L. (1989). What Managers Think of Capital Structures Theory: A Survey. Financial Management, vol 23, 82-91.

Pradhan, R. S. (2006). Research in Nepalese Finance, Kathmandu: Buddha Academic Publishers and Distributors.

Pradhan, R.S. and Ang, J.S. (1994). A Comparison of Financial Management Practices in Nepal Among Government-Owned, Publicly Traded and Privately Held Firms. Studies in the Financial Markets of the Pacific Basin, vol 11, 139-163.

Scott Jr, D. F., and Johnson, D. J. (1982). Financing policies and practices in large corporations. Financial Management, 51-59.

Sherpa, L.G. (2007).Corporate Capital Structure and Its Determinants: A Case of Nepal. Unpublished M.Phil.thesis, Faculty of Management, Tribhuvan University, Kathmandu.

Silwal, P.P. (2015). Discriminant Analysis for Corporate Debt equity Decision: Evidence from Nepal. The Lumbini Journal of Business and Economics, vol. 5 (1),pp 72-85.

Smith, C. and Warner, J. (1979). Bankruptcy, Secured Debt, and Optimal Capital structure: Comments. Journal of Finance, vol 34, 247-252.

Smith, Jr., C.W. (1986). Investment Banking and the Capital Acquisition Process. Journal of Financial Economics, vol. 15, 3-29.

Titman,S. and Wessels, R. (1988). The Determinants of Capital Structure Choice. Journal of Finance, vol. 43, 1-18. 
90 | The International Research Journal of Management Science

Vol. 2 No. 1 Decm.2017/ISSN 2542-2510

Appendix 1: The responses of survey of financial executives on capital structure practices in Nepal and results of chisquare test.

\begin{tabular}{|c|c|c|c|c|c|c|c|c|}
\hline & & MF & NMF & Total & $\mathrm{DF}$ & Chi-sq & $5 \%$ level & Remark \\
\hline Question no. & Yes & 35 & 34 & 69 & & & & \\
\hline \multirow[t]{2}{*}{2} & No & 8 & 9 & 17 & & & & \\
\hline & Total & 43 & 43 & 86 & 1 & 0.073 & 3.84 & NS \\
\hline \multirow[t]{4}{*}{3} & Yes & 33 & 27 & 60 & & & & \\
\hline & No & 1 & 10 & 11 & & & & \\
\hline & Don't know & 9 & 6 & 15 & & & & \\
\hline & Total & 43 & 43 & 86 & 2 & 8.564 & 5.99 & $\mathrm{~S}$ \\
\hline \multirow[t]{4}{*}{4} & Yes & 37 & 33 & 70 & & & & \\
\hline & No & 2 & 2 & 4 & & & & \\
\hline & Don't know & 4 & 8 & 12 & & & & \\
\hline & Total & 43 & 43 & 86 & 2 & 1.56 & 5.99 & NS \\
\hline \multirow[t]{4}{*}{5} & Yes & 38 & 32 & 70 & & & & \\
\hline & No & 3 & 4 & 7 & & & & \\
\hline & Don't know & 2 & 7 & 9 & & & & \\
\hline & Total & 43 & 43 & 86 & 2 & 3.43 & 5.99 & NS \\
\hline \multirow[t]{4}{*}{$6 \mathrm{a}$} & Agree & 36 & 31 & 67 & & & & \\
\hline & Disagree & 4 & 7 & 11 & & & & \\
\hline & Don't know & 3 & 5 & 8 & & & & \\
\hline & Total & 43 & 43 & 86 & 2 & 1.69 & 5.99 & NS \\
\hline \multirow[t]{4}{*}{$6 \mathrm{~b}$} & Agree & 37 & 36 & 73 & & & & \\
\hline & Disagree & 4 & 4 & 8 & & & & \\
\hline & Don't know & 2 & 3 & 5 & & & & \\
\hline & Total & 43 & 43 & 86 & 2 & 0.214 & 5.99 & NS \\
\hline \multirow[t]{4}{*}{$7 \mathrm{a}$} & Agree & 7 & 7 & 14 & & & & \\
\hline & Disagree & 33 & 33 & 66 & & & & \\
\hline & Don't know & 3 & 3 & 6 & & & & \\
\hline & Total & 43 & 43 & 86 & 2 & 0.00 & 5.99 & NS \\
\hline \multirow[t]{4}{*}{$7 b$} & Agree & 34 & 34 & 68 & & & & \\
\hline & Disagree & 7 & 6 & 13 & & & & \\
\hline & Don't know & 2 & 3 & 5 & & & & \\
\hline & Total & 43 & 43 & 86 & 2 & 0.277 & 5.99 & NS \\
\hline
\end{tabular}

1. The difference is significant if the computed value of chi-square is greater than the tabular value

2. DF means degree of freedom

3. S stands significant and NS stands for non-significant 